\title{
THE DEVELOPMENT OF RIVER CRUISING TOURISM AS A POTENTIALLY POSITIVE RESULT OF THE DEVELOPMENT OF INLAND WATERWAYS IN POLAND
}

\author{
ARTUR POMIANOWSKI \\ University of Szczecin, Faculty of Management and Economics of Services, POLAND \\ e-mail: arturpomianowski@gmail.com
}

RECEIVED

ACCEPTED

JEL

CLASSIFICATION

KEYWORDS

ABSTRACT
10 December 2018

28 December 2018

O18, P48, R10, Z32

river cruising, tourism, regional economics, inland waterway infrastructure

The development of waterways obviously means an increase in the transport accessibility of areas within their reach. It provides an opportunity to reduce congestion on roads and railways and leads to low-emission transport. The improvement of shipping parameters also seems to be an opportunity to attract to Poland large-scale tourism services related to river cruises. The aim of the article is to try to indicate the potential of tourist trips on river cruisers in the context of the presented waterway development plans. Demonstrating them should be an additional argument for the development of this mode of transport.

\section{Introduction}

The article attempts to show the potential role of river tourism with the use of river cruisers in the context of the planned development of waterways in Poland. This issue is often omitted in the discussion on the development of inland waterway transport infrastructure. The main issues addressed are the accessibility for freight transport, especially mass and containerized transport, as well as issues related to environmental protection. Attention is also 
focused primarily on the energy efficiency of water transport in relation to the unit of goods, but also on the impact of the development of waterways on the environment. The spatial scope of this article is Poland with references to other countries, mainly German, connected by the European system of inland waterways. Most sources, as well as observations, whether statistical inference refers to the period after 2010, references to literature date back to 2002. Conclusions from the article may be important for local governments and entrepreneurs, who want to be ready to take advantage of new opportunities that will bring investment in waterways.

\section{River cruising and the potential impact of this service in Poland}

While discussing potential services - in this case, tourism - which may appear on the Polish market in connection with the development of water infrastructure, it seems appropriate to approximate the problem of river cruising itself and determine the potential area of its operation. As defined by Mańkowska and Mańkowski, "River Cruise (German Flusskreuzfahrten) is a form of water tourism conducted onboard luxury river cruise ships (river cruisers) along inland waterways, comprising both short cruises on small distances, as well as multi-day trips on longer routes and including visiting attractive places and tourist spots. This form of spending free time is for tourists an optimal combination of recreational and sightseeing values as cruises take place along the route of regions and towns attractive in terms of landscape and history" (Mańkowska, Mańkowski, 2011, p. 165).

The "European agreement on main inland waterways of international importance" (AGN) adopted by the authorities of the Republic of Poland can be considered as the key to determining the area. In Poland, there are 238 communes situated on the waterways included in the AGN contract. They are located in the area of eleven voivodships: Dolnośląskie, Kujawsko-Pomorskie, Lubelskie, Lubuskie, Mazowieckie, Opolskie, Podlasie, Pomorskie, Śląskie, Wielkopolskie and Zachodniopomorskie. The number of communes in the different voivodships covered by the survey varies from 4 to 43 , as shown in Table 1.

Tahle 1. Communes covered by the study with division into voivodships

\begin{tabular}{|c|c|c|}
\hline Item & Voivodship & Number of communes \\
\hline 1. & Dolnośląskie & 23 \\
\hline 2. & Kujawsko-Pomorskie & 34 \\
\hline 3. & Lubelskie & 6 \\
\hline 4. & Lubuskie & 29 \\
\hline 5. & Mazowieckie & 43 \\
\hline 6. & Opolskie & 19 \\
\hline 7. & Podlaskie & 4 \\
\hline 8. & Pomorskie & 22 \\
\hline 9. & Śląskie & 8 \\
\hline 10. & Warmińsko-Mazurskie & 5 \\
\hline 11. & Wielkopolskie & 13 \\
\hline 12. & Zachodniopomorskie & 13 \\
\hline
\end{tabular}

Source: own study on base of data provided by KZGW and Państwowe Gospodarstwo Wodne Wody Polskie.

In total, around 6.9 million people live in all communes located over the waterways covered by the AGN contract. This constitutes over 17 per cent of the population of Poland (GUS, 2017). These communes include Warsaw, 
Wrocław, Gdańsk, Szczecin, Bydgoszcz and Toruń. This is the situation when only communes located directly on waterways are taken into account. On the other hand, it seems more appropriate to include in the considerations on tourist importance also those communes which are located in the area of the influence of waterways. In the case of tourist cruises, the area of influence could be determined by the time that is needed to get to a given place, e.g. a tourist attraction, from an existing or potential port. It is difficult to clearly define the boundary of this area of influence. A precise definition of this area is difficult; however, the range that may be covered in two or, in extreme cases, three hours by coach, i.e. no more than about $200 \mathrm{~km}$ from the port, will be adopted for the purposes of the article. Such an approach is also represented by entrepreneurs in this industry, as the ship rarely stands at the wharf for more than a day. This means that optional excursions are available for the participants of the cruise, lasting along with commuting up to about 10 hours. The assumption of such parameters allows for the assumption that tourist attractions from the majority of Poland can be an incentive for tourists. The regions that seem to be outside the area of waterways impact in this tourist aspect include the part of the Świętokrzyskie Voivodship, the southern part of the Lubelskie Voivodship, the eastern and southern parts of the Małopolskie Voivodship, the northern part of the Podlaskie Voivodship, the eastern part of the Warmińsko-Mazurskie Voivodship and the Podkarpackie Voivodship. At the same time, it is necessary to be aware that for the development of river cruise tourism, the prevailing attractions should be located along the cruise routes and in the port cities themselves, and those available with the use of a coach can only be complementary as optional excursions available for the cruise participants. The aim of the article is not to point out attractions and products available to potential tourists; suffice is to understand that there are many of them and how much potential they represent for the development of this type of tourism. Examples include: Gdańsk with the Artus Court, the Crane Gate, the Teutonic Castle in Malbork, Warsaw with the Royal Castle and the Old Town, Torun with the Planetarium or the Gingerbread Museum, Wrocław with the Centennial Hall, Panorama Racławicka and Ostrow Tumski, or last but not least Szczecin with the Chrobry Embankment at the foot of which river cruisers moor. The quoted examples seem to fulfil the assumptions about the places attracting tourists, proposed by Mulec and Wise in the context of attracting tourists to the Vojvodina region in Serbia "To become a successful and competitive tourism destination, all destinations must strategically promote specific location endowments that distinguish one place from another. In this regard, tourism experts, tour operators, and travel agents, in addition to independent travellers, acquire knowledge and awareness" (Mulec, Wise, 2012).

\section{Linear infrastructure and the size of the river cruisers market in Germany and Poland}

The offering of attractions in the form of one-day or several-hour trips is possible with moderate development of waterways, as it is possible to create a vessel adapted to the requirements of a given route. That is why there are successful white fleet operators in Poland in larger riverside cities. Sometimes also water trams complement public transport, such as in Warsaw or Bydgoszcz. Another example is the several-hour connections offered between the communes located on the Odra River, such as Głogów, Bytom Odrzański, Cigacice, Słubice, Kostrzyn upon Oder or Nowa Sól, and even the German side of Frankfurt on the Oder River.

On the other hand, multi-day cruises, usually on a circular route, are conducted with ships of similar parameters and thus require an appropriate stable minimum standard - the waterway class. It should, of course, also mean the stability of these parameters, especially in the period that can be regarded in this case as the tourist season. The period from the beginning of April to the end of September is in Europe considered a season in this industry; 
sometimes its wider perception is taken into account - from mid-March to mid-October. An exemplary comparison of vessels that perform transport in a circular formula, i.e. river cruisers, is included in Table 2.

Table 2. Parameters of selected cruisers sailing on European waterways

\begin{tabular}{lcccr}
\hline \multicolumn{1}{c}{ Vessel's name } & Length $(\mathrm{m})$ & Width $(\mathrm{m})$ & Draft $(\mathrm{m})$ & Number of passengers \\
\hline MS Johannes Brahms & 81.95 & 9.50 & 1.30 & 80 \\
A-Rosa Aqua & 135.00 & 11.40 & 1.70 & 202 \\
MS River Explorer & 125.50 & 11.40 & 1.50 & 168 \\
MS Frederic Chopin & 83.00 & 9.50 & 1.10 & 80 \\
MS Mona Lisa & 82.00 & 10.00 & 0.90 & 100 \\
MS Sans Souci & 82.00 & 9.50 & 1.30 & 81 \\
MS Victor Hugo & 82.00 & 9.50 & No data & 96 \\
MT Sonata & 135.00 & 11.4 & No data & 186 \\
\hline
\end{tabular}

Source: own study on the basis of: www.vesselfinder.com; www.hansatouristik.de/ms-johannesbrahms.html; https://www.croisieurope.travel/ en/boats/european-river-cruise-ships; https://www.nicko-cruises.de/en/fleet/ship; https://www.riverscanner.com/ship-a-rosa-aqua; http://www. ms-sanssouci.de/ueberuns/dasschiff/index.html.

From the data presented in the table, it can be assumed that for the development of cruising water tourism, and especially for attracting cruise operators from other countries, a class IV waterway should be provided, however, often occurring passenger ships usually have much lower requirements for waterway parameters under in terms of the draft $(0.9 \mathrm{~m}-1.3 \mathrm{~m})$ than the maximum length or clearance under the bridges.

Due to the condition of waterways in Poland, currently on the routes of operators of tourist river cruisers such as Phoenix, Nicko Cruises Schiffsreisen $\mathrm{GmbH}$, Plantours Kreuzfahrten or Croisi Europe, which is shown in Figure 1, out of Polish cities, Szczecin and Wrocław are on the list of their destinations. Except that, Wrocław only in March, i.e. at the beginning of the season, due to the higher water level during this period, which facilitates safe navigation. The occurrence of the Oder's cities in this list results from the availability of high-class waterways in the vicinity of Szczecin as well as the communication of the Oder Waterway with the German network of waterways, including the Oder - Havel canal.

Table 3. River cruisers and passengers on ships arriving in Szczecin in 2011-2016

\begin{tabular}{ccc}
\hline Years & The number of callings at a port by river cruisers & Number of passengers \\
\hline 2011 & 89 & 6,230 \\
2012 & 84 & 5,880 \\
2013 & 90 & 6,300 \\
2014 & 100 & 7,000 \\
2015 & 107 & 7,490 \\
2016 & 102 & 7,140 \\
\hline
\end{tabular}

Source: own study based on data of Wizyty...(2018) and data of Żegluga Szczecińska Turystyka i Wydarzenia sp. z o. 0.

It should be noted that currently there is a boat lift on this canal, whose parameters limit the movement of vessels of over 83 meters in length. However, during the creation of this article, another lift is being built that will 
allow vessels of up to $114 \mathrm{~m}$ to be moved (Wasser- und Schifffahrtsverwaltung..., 2010). According to data provided by the Szczecin and Świnoujście Seaports Authority SA (ZMPSiŚ), as presented in Table 3, the number of river cruisers calling at the most popular in this respect city in Poland - Szczecin, amounts to 107 vessels per year, and the number of passengers can reach almost 7.5 thousand.

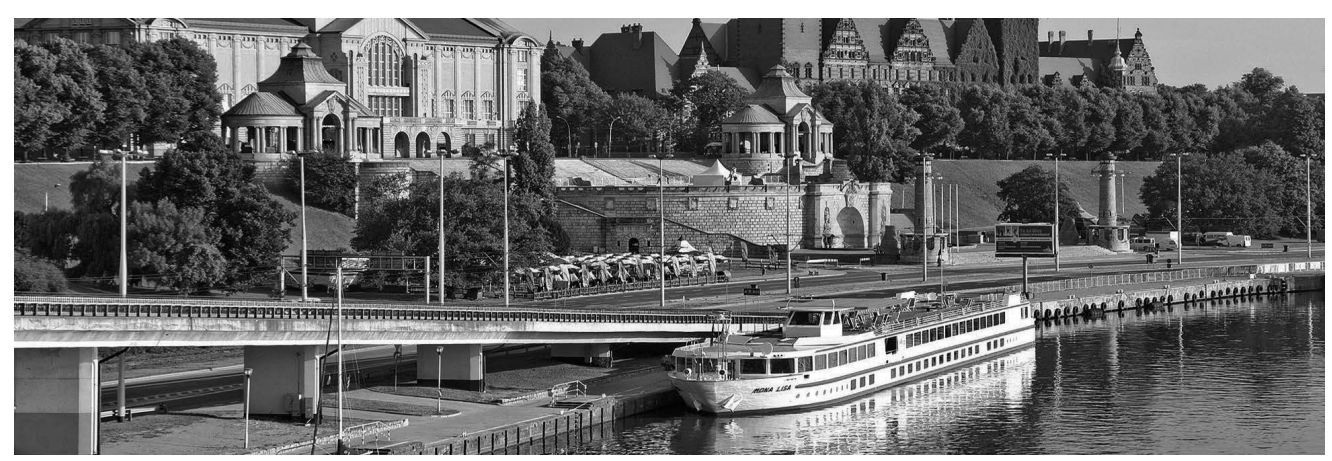

Figure 1. River cruiser MS Mona Lisa in Szczecin

Source: MS Mona Lisa (2018).

It seems appropriate to analyze the popularity of recreation in a country with a similar climate as in Poland and an extensive network of waterways. Germany is a good example. The size of the market serviced by German operators is shown in Table 4. It should be noted, however, that not all cruises run exclusively on the territory of that country, sometimes they only begin and/or end there. Cruises of this type usually last about 7 days, and their cost for the participant is on average around 1,000 Euro. It should be emphasized that the number of passengers in recent years has been stable.

Table 4. River excursions market in Germany in 2012-2016

\begin{tabular}{lccccc}
\hline \multicolumn{1}{c}{ Years } & 2012 & 2013 & 2014 & 2015 & 2016 \\
\hline Turnover in millions of Euros & 455 & 417 & 396 & 435 & 449 \\
Number of passengers & 436,628 & 406,614 & 415,858 & 423,635 & 435,586 \\
\hline
\end{tabular}

Source: Fakten und zahlen zum deutschen Reisemarkt, for years: 2012, 2013, 2014, 2015 and 2016 after Deutschen Reise Verbands...(2018) - Berlin for years: 2012, 2013, 2014, 2015, and 2016.

In 2017, Poland was visited by 18.7 million tourists (Ministerstwo Sportu i Turystyki, 2018). Thus, the emergence of a new branch that could potentially attract several hundred thousand visitors more seems significant. Especially that in recent years, the number of people using this form of tourism in Poland does not exceed even 10,000 per year, and as indicated in table 4 in Germany it is over 40 times more. 


\section{Possibilities of tourism development using river cruisers in Poland}

The arguments for the attractiveness of Poland for this type of tourism are many. The more important ones include:

- natural values of rivers and riversides in Poland (often covered by the Birds and Habitats Directives),

- the majority of the most popular and largest cities (tourist attractions) lie on the waterways covered by the AGN, ${ }^{1}$

- increase in the wealth of the society,

- proximity to countries with rich societies interested in this form of recreation,

- searching for new destinations by tourists - the effect of novelty in the first decade of this branch in Poland,

- relatively low prices of services.

Problems in the development of this branch include:

- lack of experienced staff,

- lack of domestic carriers specializing in this type of tourism,

- a long-term infrastructure development process,

- seasonality,

- habits related to the type of recreation,

- ignorance of the product.

However, the benefits that the development of this service brings to the communes chosen by the operators of river cruisers as destinations are essential. At the same time, it should be pointed out, as if extrapolating K. Woś thought about Szczecin, that it is necessary for the communes to improve the city's accessibility from inland waters and build an appropriate technical base as well as provide appropriate service facilities for passenger transport (Woś, 2005, p. 217). Without such actions, it is impossible to convince operators to visit a given commune. When talking about service facilities, the author is convinced that the attractions, monuments, museums and a cultural offer should be especially taken into consideration, but also the availability of guides and their command of languages (German, English, French, Spanish and Swedish). The availability of coach transport services and a rich gastronomic base are also important.

The benefits of the regular appearance of cruisers include:

a) income of owners/operators of wharfs;

b) increased demand for guide services;

c) increased demand for coach transport for optional trips;

d) increased recognition of a given place in the world;

e) revenues of local entrepreneurs, especially in such industries as:

- gastronomy,

- the sale of souvenirs,

- currency exchange - exchange offices;

f) new workplaces;

${ }^{1}$ The exceptions are Kraków and Łódź. In the case of Krakow, the construction of the Silesian Canal may include it in the waterway network and may be a supplement to the Oder route, e.g. as the next stop after Wrocław. 
g) increase in revenue of local government units and the state treasury in connection with income taxes on the PIT, CIT or VAT and excise duty;

h) accommodation facilities (if the place is the starting or ending port).

\section{Conclusions}

The above-mentioned arguments, as well as the potential benefits of tourism development based on the so-called river cruisers, allow for an assumption that the development of this branch of tourism can be a further development impulse for Poland and should be taken into account in all analyzes of potential benefits related to investments in inland waterway transport infrastructure. At the same time, attention should be paid to the fact that in Germany many operators are active in this sector, and there is a considerable interest in this type of tourism. Combining this with the historical conditions of the cities located on the Oder, it can be concluded that the fastest and priority development of this waterway, already communicated with the European waterway system, seems to have a significant development potential and can be very popular. The waterways of western Poland are also the easiest to reach for the inhabitants of Scandinavia, which can also make them attractive.

The observation of a well-functioning over 40 times larger market of river cruisers in Germany provides a supposition that the assumption will be favourably received also in Poland. These conclusions are still valid even considering the differences both in area and population as well as wealth. In addition, Germany has numerous transport links with other European inland waterways, in particular with the Danube and the rivers of the Netherlands. Despite this, it can be assumed with a high degree of probability that there are considerable opportunities to develop this form of recreation and its popularity in Poland, of course, assuming the preceding development of inland waterway transport infrastructure in the country. A particularly important condition is the improvement of the parameters of waterways and passenger infrastructure on quays in representative city points.

\section{Referencens}

Deutschen Reise Verbands, Fakten und Zahlen zum Reisemarkt (2018). Retrieved from: https://www.drv.de/fachthemen/statistik-undmarktforschung/fakten-und-zahlen-zum-reisemarkt.html.

GUS (2017). Population. Size and structure of population and vital statistics in Poland by territorial division in 2016 as of December 31. Statistical information and elaboration. Warsaw.

https://www.croisieurope.travel/en/boats/european-river-cruise-ships.

https://www.nicko-cruises.de/en/fleet/ship.

https://www.riverscanner.com/ship-a-rosa-aqua.

Mańkowska, M., Mańkowski, T. (2011). Cruising rzeczny jako determinanta kształtowania produktu turystycznego Szczecina. Zeszyty Naukowe Uniwersytetu Szczecińskiego. 627, Ekonomiczne Problemy Turystyki, 16, 163-179.

Ministerstwo Sportu i Turystyki (2018). Charakterystyka przyjazdów nierezydentów do Polskiw 2017 roku. Opracowano w Departamencie Turystyki na podstawie badań statystycznych GUS-MSiT-NBP. Warszawa.

MS Mona Lisa (2018). Retrieved from: https://www.croisieurope.travel/en/boat/ms-monalisa?edition=2019\#.

Mulec, I., Wise, N. (2012). Foreign Tour Operators and Travel Agents Knowledge of a Potential Tourism Destination: The Vojvodina Region of Serbia. Managing Global Transitions, 10 (2), 171-187. Retrieved from: http://www.fm-kp.si/zalozba/ISSN/15816311/10_171-187.pdf.

Wasser- und Schifffahrtsverwaltung des Bundes Wasserstraßen -Neubauamt (2010). Berlin.

Woś, K. ( 2005). Żegluga pasażerska i jachtowa w Szczecińskim Węźle Wodnym. In: H. Salmonowicz (ed.), Transport morski i lotniczy w obsłudze ruchu pasażerskiego. Szczecin: Wydawnictwo Naukowe Uniwersytetu Szczecińskiego. 
www.hansatouristik.de/ms-johannesbrahms.html.

www.ms-sanssouci.de/ueberuns/dasschiff/index.html.

www.vesselfinder.com.

ZMPSiŚ SA (2018). Wizyty wycieczkowców. Retrieved from: www.port.szczecin.pl/pl/oferta/wycieczkowce/wizyty-wycieczkowców.

Cite this article aS: Pomianowski, A. (2018). The development of river cruising tourism as a potentially positive result of the development of inland waterways in Poland. European Journal of Service Management, 4 (28/2), 351-358. DOI: 10.18276/ejsm.2018.28/2-41. 